\title{
Tiotidine, a Histamine H2 Receptor Inverse Agonist That Binds with High Affinity to an Inactive G-Protein-Coupled Form of the Receptor. Experimental Support for the Cubic Ternary Complex Model
}

\author{
FEDERICO MONCZOR, NATALIA FERNÁNDEZ, BIBIANA LEMOS LEGNAZZI, MARIA EUGENIA RIVEIRO, \\ ALBERTO BALDI, CARINA SHAYO, and CARLOS DAVIO \\ Laboratorio de Radioisótopos, Facultad de Farmacia y Bioquímica (F.M., N.F., B.L.L., M.E.R., C.D.) and Departamento de Fisiología, Biología \\ Molecular y Celular, Facultad de Ciencias Exactas y Naturales (C.S.), Universidad de Buenos Aires, Argentina; Consejo Nacional de \\ Investigaciones Científicas y Técnicas, Buenos Aires, Argentina (F.M., N.F., A.B., C.S., C.D.); and Instituto de Biología y Medicina \\ Experimental, Buenos Aires, Argentina (N.F., A.B., C.S.)
}

Received January 27, 2003; accepted May 13, 2003

This article is available online at http://molpharm.aspetjournals.org

\begin{abstract}
Knowing the importance for research and pharmacological uses of proper ligand classification into agonists, inverse agonists, and antagonists, the aim of this work was to study the behavior of tiotidine, a controversial histamine $\mathrm{H} 2$ receptor ligand. We found that tiotidine, described previously as an $\mathrm{H}_{2}$ antagonist, actually behaves as an inverse agonist in U-937 cells, diminishing basal cAMP levels. $\left[{ }^{3} \mathrm{H}\right]$ Tiotidine showed two binding sites, one with high affinity and low capacity and the other with low affinity and high capacity. The former site disappeared in the presence of guanosine 5'-O-(3-thio)triphosphate, indicating that it belongs to a subset of receptors coupled to G-protein, showing the classic binding profile for an agonist. Considering the occupancy models developed up to now, the only one that explains tiotidine dual behavior is the
\end{abstract}

cubic ternary complex (CTC) model. This model allows Gprotein to interact with the receptor even in the inactive state. We showed by theoretical simulations based on the CTC model of dose-response and binding experiments that tiotidine biases the system to a G-protein-coupled form of the receptor that is unable to evoke a response. This theoretical approach was supported by experimental results in which an unrelated Gprotein-coupled receptor that also signals through $\mathrm{G} \alpha_{\mathrm{s}}$-protein ( $\beta_{2}$-adrenoreceptor) was impeded by tiotidine. This interference clearly implies that tiotidine biases the system to $\mathrm{G} \alpha_{\mathrm{s}}$-coupled form of the $\mathrm{H} 2$ receptor and turns $\mathrm{G} \alpha_{\mathrm{s}}$-protein less available to interact with $\beta_{2}$-adrenoreceptor. These findings not only show that tiotidine is an $\mathrm{H} 2$ inverse agonist in $\mathrm{U}-937$ cells but also provide experimental support for the CTC model.

Receptors coupled to G-proteins (GPCRs) play a major role in signal transduction and are the targets for a large number of therapeutic drugs. Although much is known about signal transduction pathways, the mechanism by which ligands bind to and activate GPCRs remains unclear. In an attempt to understand such mechanisms, several occupancy models have been developed. The first theoretical model of receptor function that included G-proteins was the ternary complex model of De Léan et al. (1980) in which the receptor possesses two binding sites, one for the ligand on the extracellular side and other for the G-protein in the intracellular side. This

This study was supported by grants from the Universidad de Buenos Aires (grant BO22); Consejo Nacional de Investigaciones Científicas y Tecnológicas (PID 792/98); Agencia Nacional de Promoción Científica y Técnológica (PICT 9805-03514); and Ministerio de Salud de la Nación Argentina (CarrilloOñativia grant). model is a generalization of former models, in which only the free receptor and the receptor ligand complex existed, allowing receptors to interact with ligands as well as G-proteins. An important advancement in the understanding of GPCRs was the recognition that they could couple to and functionally activate G-proteins even in the absence of an agonist. This receptor feature was suggested by the identification of constitutively activated mutant forms of several receptors (CAM receptors), such as $\alpha_{1 \mathrm{~B}}$ adrenoreceptor (Kjelsberg et al., 1992), thyrotropin receptor (Parma et al., 1993), and luteinizing hormone receptor (Shenker et al., 1993). These experimental results led to the extended ternary complex model (ETC) (Samama et al., 1993), which includes two distinct conformational states of the receptor, an active $\left(\mathrm{R}^{*}\right)$ and an inactive $(\mathrm{R})$ state, that exist in equilibrium even in the absence of drugs. This spontaneous equilibrium determines 
basal activity, and in CAM receptors, it is driven toward $\mathrm{R}^{*}$, increasing the response in the absence of drugs. A further modification of the ETC model is the cubic ternary complex model (CTC) (Weiss et al., 1996a,b,c), which completes the ETC model by allowing G-proteins to interact with receptors in both their active and inactive states $\left(R^{*} G, L R^{*} G\right.$, and $R G$, LRG).

These two models account for the effects of different types of ligands on receptor signaling. Agonists increase receptor activity, neutral antagonists have no effect on it, and inverse agonists are able to reduce the activity of receptor systems that are active in the absence of agonists.

Although initially drugs were classified as agonists and neutral antagonist, now it is considered that ligands have an efficacy ranging from agonism through neutral antagonism to inverse agonism. In fact, many drugs with important therapeutic actions that were originally described as neutral antagonists are actually inverse agonists. Examples of this are cimetidine [selective histamine $\mathrm{H} 2$ receptor (H2r) ligand] (Smit et al., 1996), haloperidol (which acts on dopamine $\mathrm{D}_{2}$ receptors) (Hall and Strange, 1997), prazosin ( $\alpha_{1}$-adrenoreceptor ligand) (Rossier et al., 1999), timolol (which acts on $\beta_{2}$-adrenoreceptor) (Chidiac et al., 1994), and clozapine (which acts on $\mathrm{D}_{2}$ and $5-\mathrm{HT}_{2 \mathrm{C}}$ receptors) (Westphal and Sanders-Bush, 1994; Hall and Strange, 1997).

$\mathrm{H} 2 \mathrm{r}$ have the regulatory functions of histamine during cell proliferation, gastric acid secretion, airway and vascular smooth muscle relaxation and immune responses (Del Valle and Gantz, 1997). Furthermore, some histamine H2 antagonists are effectively used as therapeutical agents, such as ranitidine, which is effective in the modulation of gastric acid secretion. Taking into account that treatment with antagonists would not be effective for several pathologies associated with point mutations in GPCRs that lead to increased basal receptor activity and, on the other hand, that long-term administration of some inverse agonists leads to the development of tolerance and increased sensitivity after withdrawal, it is highly important to differentiate between neutral antagonists and inverse agonists.

The presence of H2r showing typical pharmacological profile and G-protein-mediated adenylyl cyclase stimulation has been described in U-937 promonocytic cell line, which make it an adequate model to study $\mathrm{H} 2 \mathrm{r}$ signaling (Davio et al., 1995a). However, in these cells, tiotidine, previously reported as an $\mathrm{H} 2$ specific antagonist, showed inverse agonist characteristics (Monczor et al., 1998). The suitability of tiotidine has been a controversial issue (van der Goot and Timmerman, 2000) because of its complex binding since studies carried out in gastric mucosal cells (Batzri and Harmon, 1986) and kidney membranes (Rising and Norris, 1985) revealed the presence of several binding sites for $\left[{ }^{3} \mathrm{H}\right]$ tiotidine. On these bases, we aimed to study the atypical behavior of tiotidine in U-937 promonocytic cell line.

We found a two-site binding unusually sensitive to GTP $\gamma \mathrm{S}$ and an inverse agonist behavior that can be explained only in terms of the cubic ternary complex model. These observations suggest the existence of an inactive receptor species coupled to G-protein. These observations shed new light into the pharmacological classification of $\mathrm{H} 2$ antagonists and may offer a plausible explanation for the results previously reported by other authors and us.

\section{Materials and Methods}

\section{Materials}

Cell culture medium, DEAE-dextran, 3-isobutyl-1-methylxanthine (IBMX), cAMP, isoproterenol, and forskolin were obtained from Sigma Chemical Co. (St. Louis, MO). Fetal calf serum was obtained from Invitrogen (Carlsbad, CA). Tiotidine was obtained from Tocris Cookson Inc. (Ballwin, MO). $\left[{ }^{3} \mathrm{H}\right] \mathrm{cAMP}$ and $\left[{ }^{3} \mathrm{H}\right]$ tiotidine were purchased from PerkinElmer Life Sciences (Boston, MA). BU-E-75 was generously provided by Dr. A. Buschauer (Regensburg Universität, Regensburg, Germany). All other chemicals were of analytical grade.

\section{Plasmid}

H2r was previously cloned into the eukaryotic expression vector pCEFL (Shayo et al., 2001). Plasmid purification was performed using reagents from QIAGEN (Valencia, CA) according to the manufacturer's instructions.

\section{Cell Culture}

U-937 and COS-7 cells were cultured at $37^{\circ} \mathrm{C}$ in a humidified atmosphere with $5 \% \mathrm{CO}_{2}$ in RPMI 1640 medium and Dulbecco's modified Eagle's medium, respectively, supplemented with $10 \%$ fetal calf serum and $50 \mu \mathrm{g} / \mathrm{ml}$ gentamicin.

\section{Transient Transfection of COS-7 Cells}

Transient transfection was performed by the DEAE-dextran technique (Shayo et al., 2001). COS-7 cells plated in 35-mm dishes were transfected at $80 \%$ confluence using $1 \mu \mathrm{g}$ of plasmid. Assays were performed $48 \mathrm{~h}$ after transfection.

\section{Stable Transfection of U-937 Cells}

Cells were transfected as reported previously (Fernández et al., 2002). Briefly, cells were harvested by centrifugation from cultures in exponential growth phase, washed once in phosphate-buffered saline, and resuspended at $10^{6}$ cells $/ \mathrm{ml}$ in fresh RPMI 1640 medium on ice. Linearized pCEFL-rH2 $(10 \mu \mathrm{g})$ with SalI was added to cell suspension $(400 \mu \mathrm{l})$ and kept on ice for $5 \mathrm{~min}$. The cells and DNA were then subjected to a pulse of $150 \mathrm{~V}$ at a capacitance of $250 \mu \mathrm{F}$ using a Bio-Rad "Gene Pulser". Cells were returned to ice for $5 \mathrm{~min}$ and nonselective medium was added overnight. The next day, cells were plated on a 96 -well culture tray, switching the medium to RPMI 1640 containing $0.8 \mathrm{mg} / \mathrm{ml} \mathrm{G}-418$. After 2 to 3 weeks, the surviving clones were amplified.

\section{cAMP Assay}

Suspension Cells. Cells in Hanks' solution were supplemented with $1 \mathrm{mM}$ IBMX, at a density of $10^{6}$ cells $/ \mathrm{ml}$, preincubated for $3 \mathrm{~min}$ at $37^{\circ} \mathrm{C}$, and exposed for $9 \mathrm{~min}$ to different ligand concentrations. The reaction was stopped by a 3 -min centrifugation at $3,000 \mathrm{~g}$. For cAMP extraction, ethanol was added to the pellet and further centrifuged $5 \mathrm{~min}$ at $3000 \mathrm{~g}$.

COS-7 Cells. Cells were incubated $3 \mathrm{~min}$ in Dulbecco's modified Eagle's medium supplemented with $1 \mathrm{mM}$ IBMX at $37^{\circ} \mathrm{C}$, and exposed for $9 \mathrm{~min}$ to the ligand at the indicated concentrations. Cells were then washed with phosphate-buffered saline and subjected to ethanol extraction followed by a 5-min centrifugation at $3,000 \mathrm{~g}$.

The ethanol phase was dried and resuspended in $50 \mathrm{mM}$ Tris- $\mathrm{HCl}$, $\mathrm{pH} 7.4$, and $0.1 \%$ bovine serum albumin. cAMP content was determined by competition of $\left[{ }^{3} \mathrm{H}\right] \mathrm{cAMP}$ for protein kinase $\mathrm{A}$, as described previously (Davio et al., 1995b).

\section{Radioligand Binding Assay}

Suspension Cells. Triplicate assays were performed in polyethylene tubes in $50 \mathrm{mM}$ Tris- $\mathrm{HCl}, \mathrm{pH}$ 7.4. For saturation studies, increasing concentrations of $\left[{ }^{3} \mathrm{H}\right]$ tiotidine were incubated with $10^{6}$ cells/tube in the absence or presence of $1 \mathrm{mM}$ histamine in a total volume of $200 \mu \mathrm{l}$. After $40 \mathrm{~min}$ at $4^{\circ} \mathrm{C}$, incubation was stopped by 
dilution with $3 \mathrm{ml}$ of ice-cold $50 \mathrm{mM}$ Tris- $\mathrm{HCl}$, pH 7.4; rapid filtration onto Whatman GF/B glass-fibers filters was performed under reduced pressure, followed by three washes with $3 \mathrm{ml}$ of ice-cold buffer.

COS-7 Cells. Triplicate assays were performed in COS-7 transfected cells in 24 multiwell plates. For saturation studies, increasing concentrations of $\left[{ }^{3} \mathrm{H}\right]$ tiotidine were incubated in the absence or presence of $1 \mu \mathrm{M}$ tiotidine in a total volume of $200 \mu \mathrm{l}$ of $50 \mathrm{mM}$ Tris-HCl, $\mathrm{pH} 7.4$. After $40 \mathrm{~min}$ at $4^{\circ} \mathrm{C}$, incubation was stopped by dilution with $3 \mathrm{ml}$ of ice-cold $50 \mathrm{mM}$ Tris-HCl, $\mathrm{pH}$ 7.4, followed by washes with ice-cold buffer.

Experiments on intact cells were carried out at $4^{\circ} \mathrm{C}$ to avoid internalization of the ligand. Kinetic studies showed that equilibrium was reached after $30 \mathrm{~min}$ and persisted for $4 \mathrm{~h}$ (data not shown).

Membrane-purified fraction was obtained by cell sonication in 50

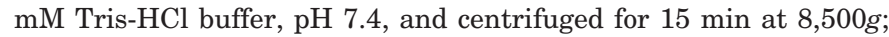
the supernatant was further centrifuged for $15 \mathrm{~min}$ at $30,000 \mathrm{~g}$. The pellet obtained was resuspended in an adequate volume.

The membrane fraction was pretreated at $37^{\circ} \mathrm{C}$ with $10 \mu \mathrm{M}$ GTP $\gamma \mathrm{S}$ for $2 \mathrm{~h}$ in Hanks' medium.

\section{Analytical Methods}

Binding data were analyzed using a weighted, nonlinear, leastsquares program that determines binding to multiple sites using the law of mass action (LIGAND program) as detailed previously (Munson and Rodbard, 1980). Sigmoidal dose-response fittings were done using Prism version 3.00 for Windows (GraphPad Software, San Diego, CA).

\section{Results}

$\left[{ }^{3} \mathrm{H}\right]$ Tiotidine Binding Assay and H2r States Identification. As is well known, agonists and inverse agonists have differential affinities for the different receptor states. For that reason, radioligand binding allows the identification of those activation states.

Binding assays using $\left[{ }^{3} \mathrm{H}\right]$ tiotidine, a specific $\mathrm{H} 2 \mathrm{r}$ ligand (described previouslyas antagonist), revealed the presence of two binding sites, one with higher affinity and lower capacity $\left(K_{\mathrm{d}_{1}}=2.2 \pm 0.8 \mathrm{nM} ; \mathrm{Q}_{1}=2,000 \pm 430 \mathrm{sites} / \mathrm{cell}\right)$ and the other with lower affinity but higher capacity $\left(K_{\mathrm{d}_{2}}=20 \pm 3\right.$ $\mathrm{nM} ; \mathrm{Q}_{2}=20,000 \pm 1800$ sites/cell) (Fig. 1). Similar results were obtained when membrane fractions were used (Fig. 2A).

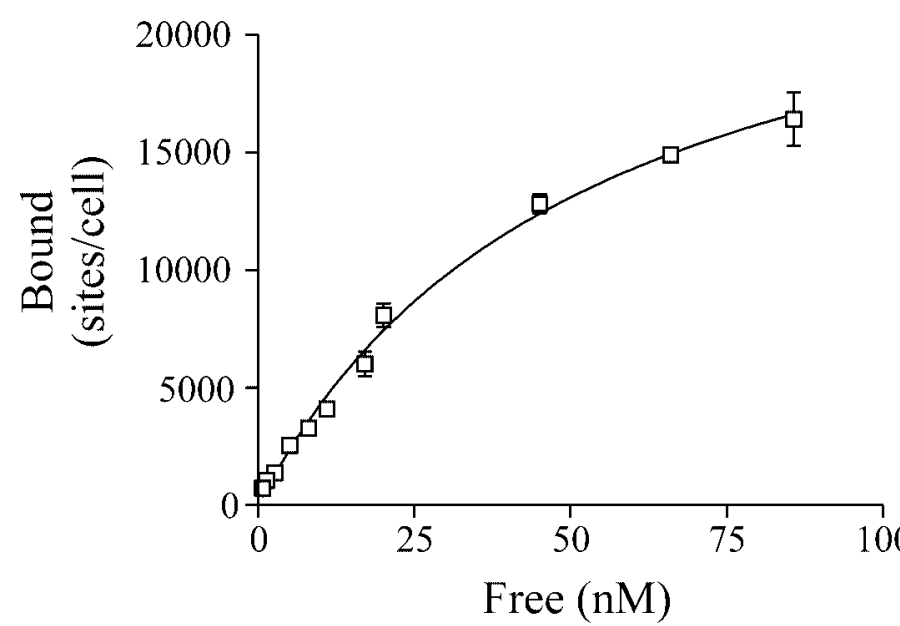

Fig. 1. $\left[{ }^{3} \mathrm{H}\right]$ Tiotidine binding assay in intact U-937 cells. Saturation assays for $\left[{ }^{3} \mathrm{H}\right]$ tiotidine. Data were calculated as the mean \pm S.D. of assay triplicates and analyzed using a weighted, nonlinear, least-squares program that determines binding to multiple sites using the law of mass action (LIGAND program), as described under Materials and Methods. Similar results were obtained in at least three independent experiments.
Because tiotidine specifically binds H2rs, these results can be explained in terms of tiotidine binding to two distinct receptor states. It is worth noting that in competitive binding experiments performed with $\left[{ }^{3} \mathrm{H}\right]$ tiotidine and various concentration of unlabeled tiotidine, famotidine, and BU-E-75, the maximal inhibition of $\left[{ }^{3} \mathrm{H}\right]$ tiotidine binding by each compound did not differ significantly from that obtained in the presence of $10 \mu \mathrm{M}$ tiotidine (data not shown). These results verify that tiotidine-labeled sites are histamine $\mathrm{H} 2$ sites.

In assays performed on membrane fractions of cells previously incubated with $10 \mu \mathrm{M}$ GTP $\gamma \mathrm{S}$, the Scatchard plot showed only one binding site corresponding to the low affinity site. As it can be observed, the number of sites with low affinity is equal to the total amount of sites without GTP $\gamma \mathrm{S}$ showed in Fig. $1\left(K_{\mathrm{d}}=20 \pm 3 \mathrm{nM}, \mathrm{Q}=22,000 \pm 1,900\right.$ sites/cell $\cong \mathrm{Q} 1+\mathrm{Q} 2)$ (Fig. 2A).

These data suggest that the high-affinity site corresponds to a subset of receptors coupled to G-protein, because it disappeared in the presence of $\mathrm{GTP} \gamma \mathrm{S}$. This is supported by
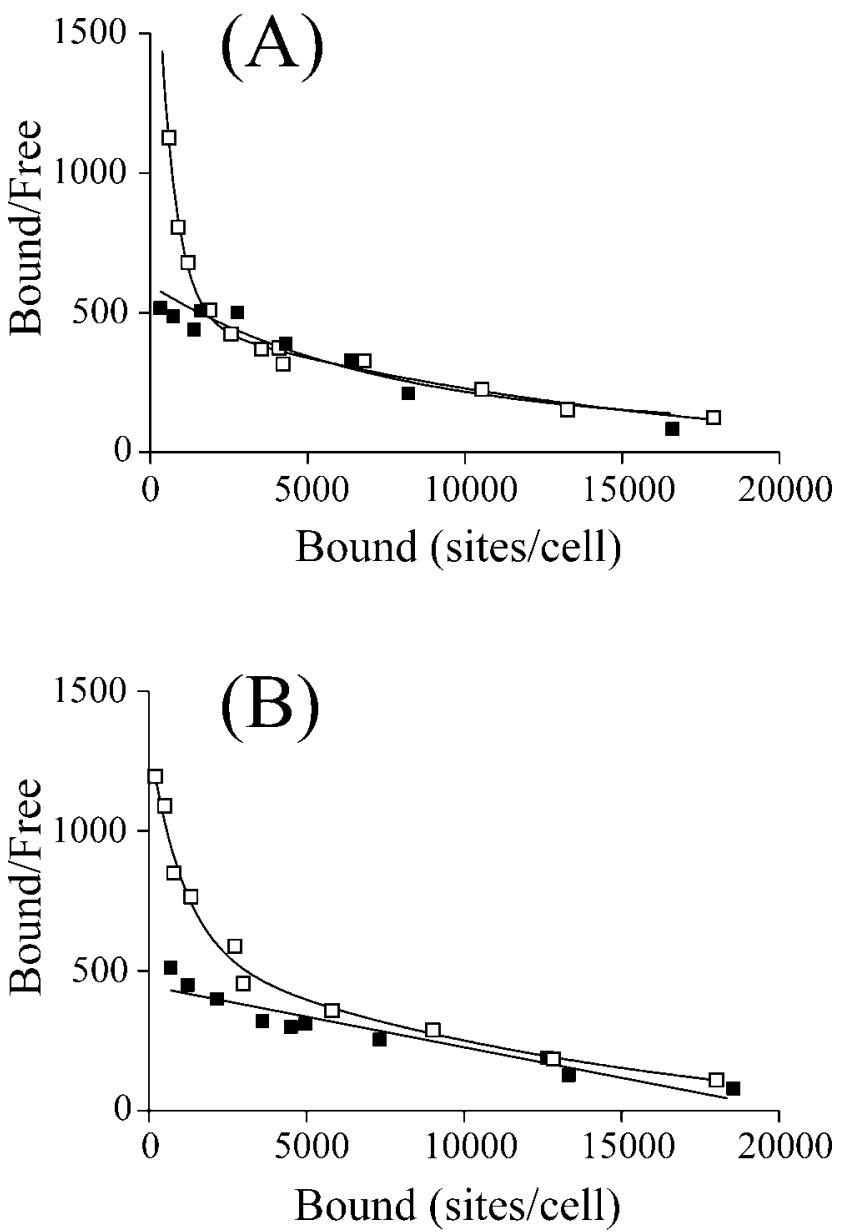

Fig. 2. $\left[{ }^{3} \mathrm{H}\right]$ Tiotidine binding assay in U-937 cells. A, Scatchard plot of saturation assays for $\left[{ }^{3} \mathrm{H}\right]$ tiotidine in U-937 membrane purified fractions treated $(\square)$ or not $(\square)$ with $10 \mu \mathrm{M}$ GTP $\gamma \mathrm{S}$ for $2 \mathrm{~h}$. Data were calculated as the mean \pm S.D. of assay triplicates. Similar results were obtained in at least three independent experiments. B, Scatchard plot of saturation assays for $\left[{ }^{3} \mathrm{H}\right]$ tiotidine in U-937 cells pretreated (ם) or not $(\square)$ with 10 $\mu \mathrm{M}$ amthamine for $2 \mathrm{~h}$. Data were calculated as the mean \pm S.D. of assay triplicates. Data were analyzed using a weighted, nonlinear, leastsquares program that determines binding to multiple sites using the law of mass action (LIGAND program) as detailed under Materials and Methods. Similar results were obtained in at least three independent experiments. 
the fact that binding assays in cells pretreated for $2 \mathrm{~h}$ with $\mathrm{H} 2$ agonist, which induces $\mathrm{H} 2 \mathrm{r}$ desensitization or uncoupling from G-protein, only showed the site with low affinity (Fig. 2B). Based on classic ligand-receptor occupancy models (the ETC model of Samama et al., 1993) in which a ligand that has more affinity for the receptor coupled to G-protein $\left(R^{*} \mathrm{G}\right)$ instead of receptor alone ( $R$ or $\left.R^{*}\right)$ necessarily bias the system to a response-evoking receptor state $\left(\mathrm{LR}^{*} \mathrm{G}\right)$, we can consider the tiotidine binding profile to be expected for an agonist. This conception is in opposition to the well established idea of tiotidine as the reference $\mathrm{H} 2$ antagonist. Therefore, we attempted to asses the ability of tiotidine to induce a second messenger signal and to block an $\mathrm{H} 2$ agonist-induced response.

Tiotidine Dose-Response Assays. In dose-response experiments carried out with BU-E-75, a specific H2 agonist, tiotidine not only produced a right shift on the $\mathrm{EC}_{50}(700 \pm$ $120 \mathrm{nM}$ versus $1,900 \pm 300 \mathrm{nM}$ ) but also diminished the maximal response achieved with the agonist from $212.8 \pm 7.7$ pmol $/ 10^{6}$ cells to $112.8 \pm 6.7 \mathrm{pmol} / 10^{6}$ cells, suggesting that tiotidine behavior is more complex than expected for a neutral antagonist. We next evaluated the effect of tiotidine on cAMP accumulation through H2r by dose-response assays. Tiotidine is able to reduce cAMP basal levels in a dosedependent manner, from $7.0 \pm 0.4 \mathrm{pmol} / 10^{6}$ cells to $1.3 \pm 0.2$ pmol $/ 10^{6}$ cells with an $\mathrm{EC}_{50}=11.5 \pm 4.5 \mathrm{nM}$ (Fig. $3, \mathrm{~A}$ and B).

To improve the sensitivity to this reduction in basal levels, different strategies that allow increasing spontaneous activity so that the negative effect of inverse agonists becomes clearly evident have been described. To achieve this, there are at least two experimental approaches; the first one involves the addition of a chemical agent that increases second messenger levels and the second one consists of receptor transfection in an overexpression system (Kenakin et al., 1995).

The first approach is based on evidence showing that inactivation of $\mathrm{G} \alpha$ s subunits decreases forskolin-induced cAMP levels. Leurs and coworkers (2002) proposed the modulation of the forskolin response by H2rs as a quite sensitive and useful tool to study inverse agonism at H2rs. The last approach is based on evidence showing that when the receptor number is increased, there is a concomitant increase in the likelihood of spontaneous receptor coupling to G-protein, which in turns leads to an increase in basal levels (Milligan, 1996).

We carried out tiotidine dose-response experiments in forskolin pretreated U-937 cells and in the heterologous system of H2r-transfected COS-7 cells. In both assays, we observed an evident decrease in cAMP levels when cells were treated with increasing tiotidine concentrations (Fig. 4, A and B). Similar results were obtained with U-937 cells overexpressing H2rs, indicating that this effect was not dependent on an intrinsic property of the COS-7 heterologous system (Fig. $4 \mathrm{C})$. It is worth noting that in both COS-7 and U-937 cells overexpressing $\mathrm{H} 2 \mathrm{r},\left[{ }^{3} \mathrm{H}\right]$ tiotidine binding profile is the same that in U-937-naive cells (data not shown).

Up to this point, the results obtained in dose-response experiments provide enough evidence to consider tiotidine as an inverse agonist. However, we can associate its binding profile with the characteristic for agonists. As can be observed, the results from binding assays disagreed with what we expected based on the classic models for inverse agonists and challenged us to analyze them using another model capable of explaining them.

Cubic Ternary Complex Receptor-Occupancy Model: a Possible Explanation for Tiotidine Behavior. The only described model capable of predicting a higher affinity for the receptor G-protein complex even for an inverse agonist is the CTC model (Fig. 5). In this way, if we consider that the species able to generate physiological responses are $R^{*} G$ and $\mathrm{LR}^{*} \mathrm{G}$, we can define a normalized factor called $f^{*}$ as the addition of that species over the total receptor amount:

$$
\begin{array}{r}
f^{*}=\frac{\left[R^{*} G\right]+\left[L R^{*} G\right]}{[R]+\left[R^{*}\right]+[R G]+\left[R^{*} G\right]+} \\
{[L R]+\left[L R^{*}\right]+[L R G]+\left[L R^{*} G\right]}
\end{array}
$$

Taking into account the model-assumed equilibrium, its related constants, and conservation equations for each compo-
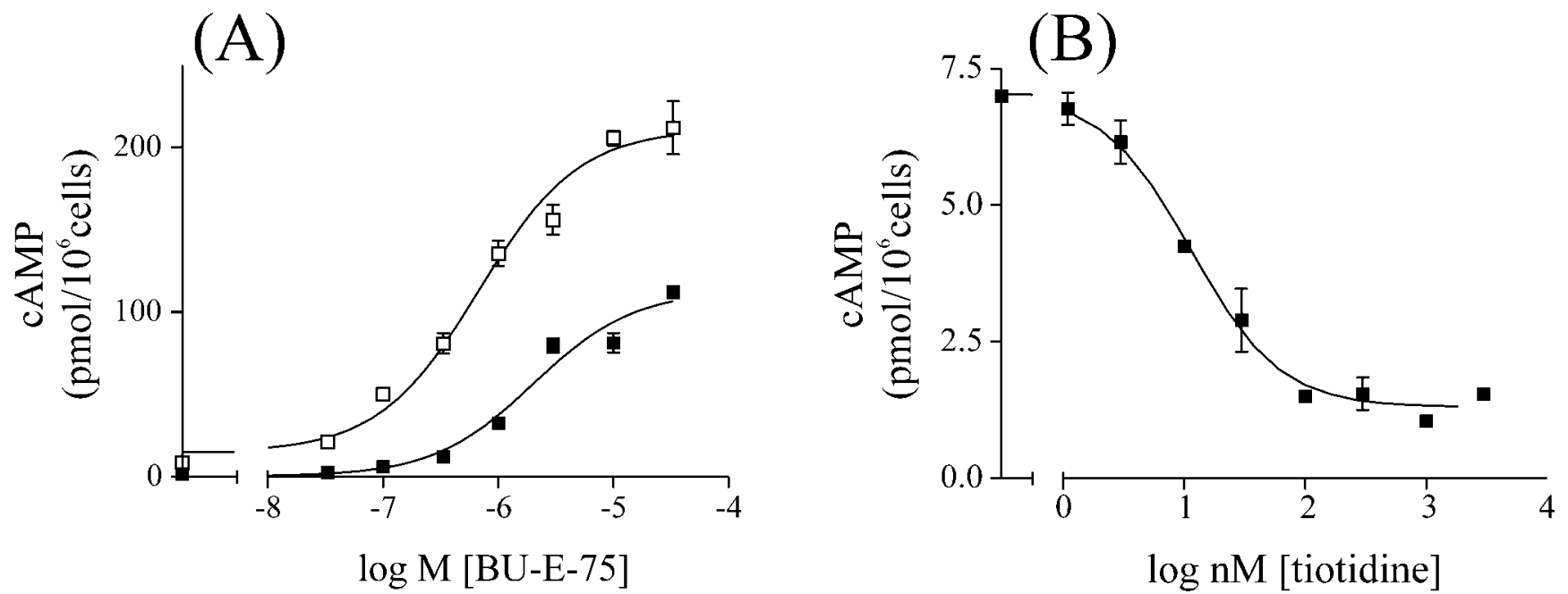

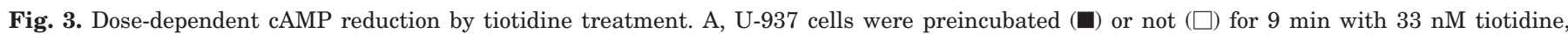

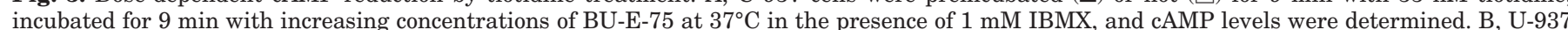

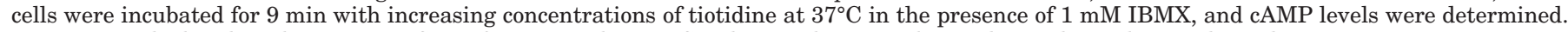
Data were calculated as the means \pm S.D. of assay triplicates. Similar results were obtained in at least three independent experiments. 


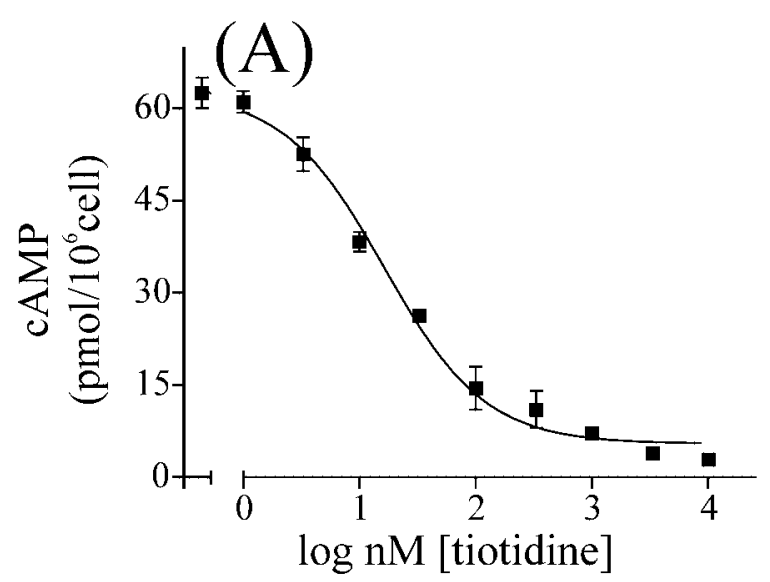

nent $(\mathrm{R}, \mathrm{G}, \mathrm{L})$, we can obtain the equation that describes $f^{*}$ variation as a function of ligand concentration (see Appendix 1).

$$
\begin{aligned}
f^{*}= & \frac{\beta \cdot K_{\mathrm{g}} \cdot K_{\mathrm{act}}[G]+\alpha \beta \gamma \delta \cdot K_{\mathrm{a}} \cdot K_{\mathrm{act}} \cdot K_{\mathrm{g}}[G][L]}{1+K_{\mathrm{act}}+K_{\mathrm{g}}[G]+\beta \cdot K_{\mathrm{g}} \cdot K_{\mathrm{act}}[G]+\left(K_{\mathrm{a}}+\alpha \cdot K_{\mathrm{a}} \cdot\right.} \\
& \left.K_{\mathrm{act}}+\gamma \cdot K_{\mathrm{a}} \cdot K_{\mathrm{g}}[G]+\alpha \beta \gamma \delta \cdot K_{\mathrm{a}} \cdot K_{\mathrm{act}} \cdot K_{\mathrm{g}}[G]\right) \cdot[L]
\end{aligned}
$$

It is worth noting that the concentration of the free G-protein $[\mathrm{G}]$ is a function of the ligand present in the system, and its value must be solved for each $L$ concentration (see Appendix 2 for further details).

If we represent $f^{*}$ as a function of $\log [L]$, we can simulate
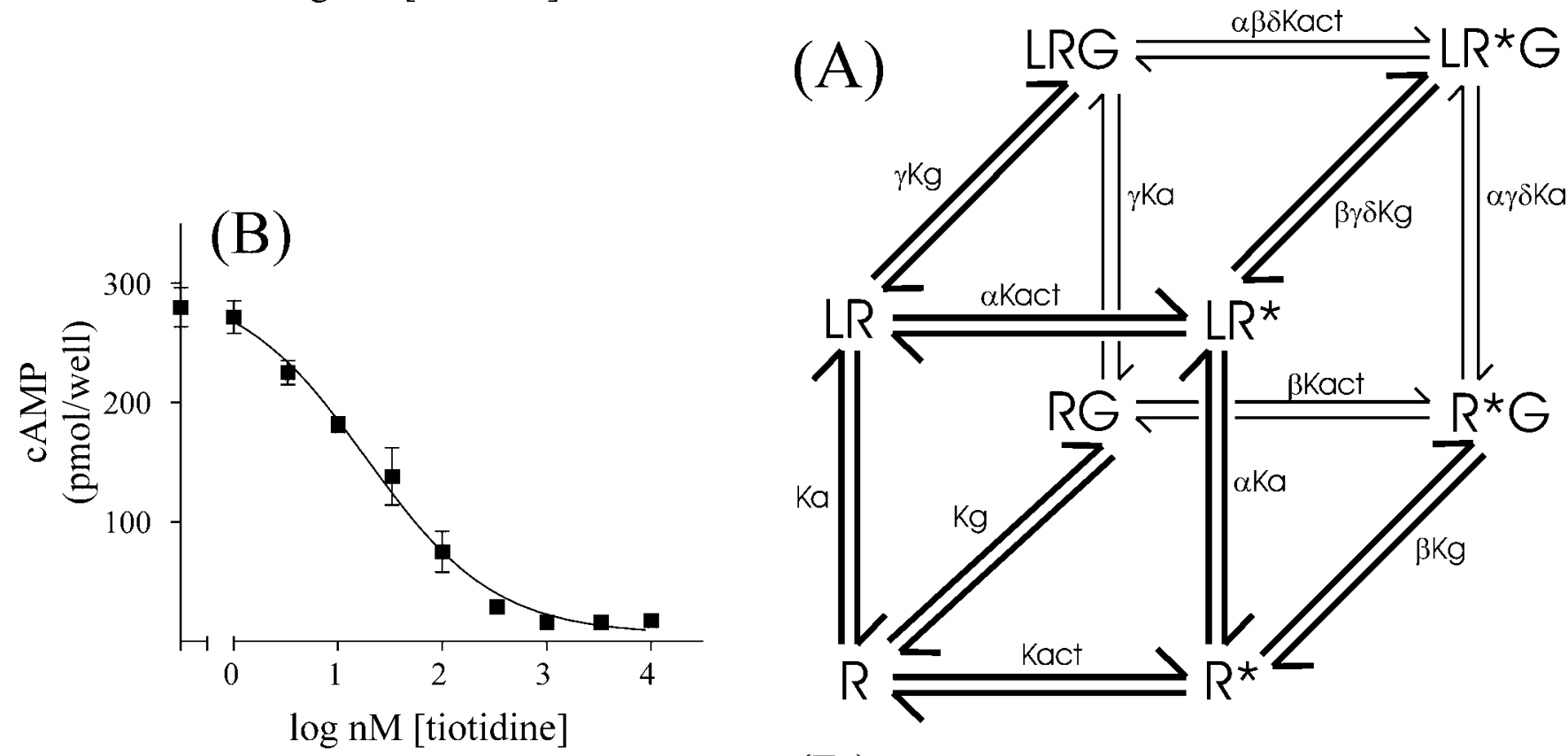

(B)

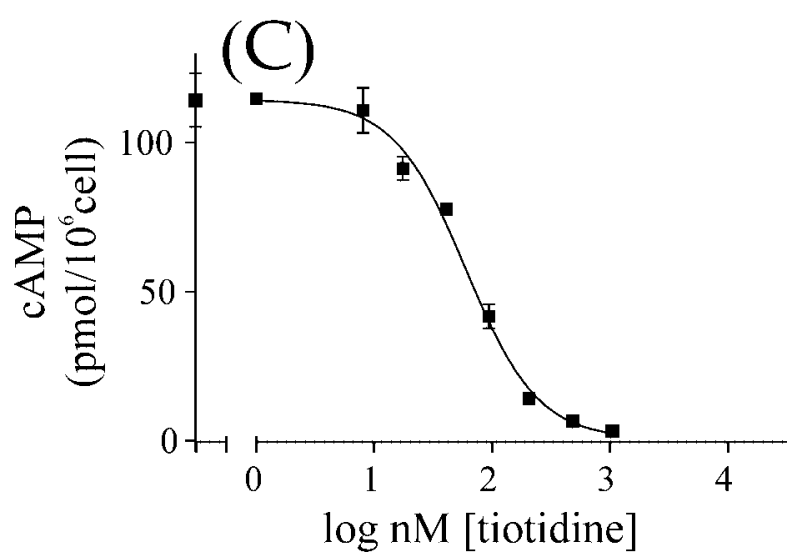

Fig. 4. Dose-dependent cAMP reduction by tiotidine treatment in systems with increased basal cAMP levels. U-937 cells pretreated with 33 $\mu \mathrm{M}$ forskolin for $3 \mathrm{~min}$ (A), COS-7 cells transfected with pCEFL-H2r (B), and U-937 cells transfected with pCEFL-H2r (C) were incubated for 9 min with increasing concentrations of tiotidine at $37^{\circ} \mathrm{C}$ in the presence of $1 \mathrm{mM}$ IBMX, and cAMP levels were determined. Data were calculated as the means \pm S.D. of assay triplicates. Similar results were obtained in at least three independent experiments.

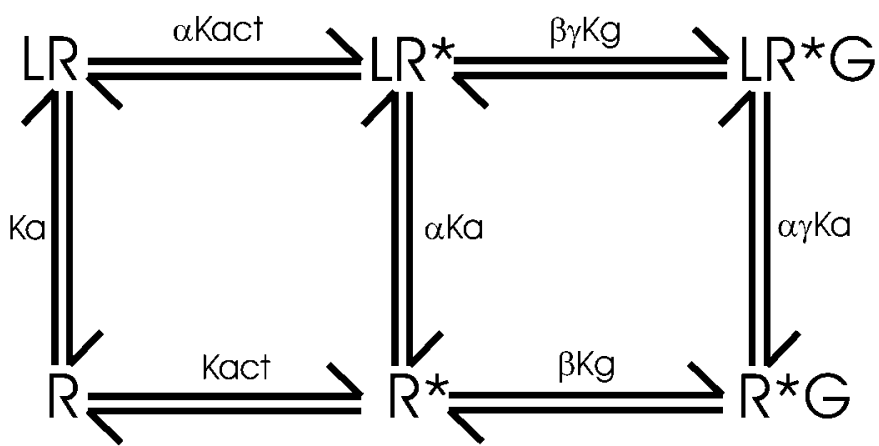

Fig. 5. A, cubic ternary complex model. CTC model whereby both inactive and active states of the receptor are allowed to interact with the Gprotein, but only $\mathrm{LR}^{*} \mathrm{G}$ mediates response (adapted from Weiss et al., 1996a,b,c). B, extended ternary complex model. ETC model assumes that only the active state of the receptor $\left(\mathrm{R}^{*}\right)$ can interact with the G-protein either spontaneously (to form $R^{*} G$ ) or through ligand binding (to form $\mathrm{LR}^{*} \mathrm{G}$ ) (adapted from Samama et al., 1993). L represents the ligand; $K_{\mathrm{a}}$ and $K_{\mathrm{g}}$ represent the association constants to ligand and G-protein, respectively; $K_{\text {act }}$ is the allosteric constant; and $\alpha, \beta$, and $\gamma$ are the modifiers of affinity once the receptor is active, G-protein-bound, or ligand-bound, respectively. $\delta$ represents the joint effect of any two parameters (receptor activation, G-protein coupling, or the binding of ligand) on the third. 
a theoretical dose-response assay for a given set of parameters. Among all parameters, $\delta$ describes the extent to which the joint effect of any two receptor modifications (i.e., receptor activation, G-protein coupling, and ligand binding) varies in relation to the third. In other words, it gives an idea of the interaction or synergism between two modifications in the receptor state over the third one. Considering that the ligand facilitates receptor activation $(\alpha>1)$, that the active receptor has more affinity for $\mathrm{G}$ protein than the inactive form $(\beta>1)$, and that the ligand improves $\mathrm{G}$ protein coupling $(\gamma>1)$, we are in the presence of an agonist for the ETC model.

However, by varying $\delta$ value in the CTC model, the ligand can behave as an agonist, an antagonist, or even as an inverse agonist (Fig. 6). In the same way, we can deduce another set of equations that describe the variation of each possible receptor state concentration $\left(R, R^{*}, R G, R^{*} G, L R\right.$, $\left.\mathrm{LR}^{*}, \mathrm{LRG}, \mathrm{LR}^{*} \mathrm{G}\right)$ as a function of ligand dose. Keeping constant the parameters mentioned above and giving $\delta$ a value that makes the ligand work as an inverse agonist, we can observe in Fig. 7, A and B, that there is a significant increase in receptor species bound to ligand but unable to evoke a biological response ([LRG] and $[L R])$.

If tiotidine biases the system to a G-protein-coupled but inactive H2r state, it can be inferred that it may interfere with the signal transduction pathway of an unrelated GPCR that also signals through a $\mathrm{G} \alpha_{\mathrm{s}}$-protein. We tested this hypothesis by stimulating U-937 cells with a $\beta_{2}$-adrenoreceptor agonist (isoproterenol) and variable doses of tiotidine. At isoproterenol $\mathrm{EC}_{50}(50 \mathrm{nM})$, tiotidine significantly diminishes isoproterenol-induced cAMP accumulation in a dose-dependent manner in more than a $60 \%$ (Fig. 8). These results agree with our prediction that tiotidine should interfere with the transduction cascade of an unrelated GPCR signaling through a $\mathrm{G} \alpha_{\mathrm{s}}$-protein, such as the $\beta_{2}$-adrenoreceptor.

We next evaluated the binding profile for a ligand with the parameters established above. To do that, we had to consider first that the affinity constant detected in a binding assay is an apparent constant, because we can measure only the fraction of receptors bound to ligands that also involves species uncoupled to G-protein $\left([L R],\left[L R^{*}\right]\right)$ and coupled to G-protein ( $\left.[L R G],\left[L R^{*} G\right]\right)$. Therefore, even in this case, in which we can differentiate between receptor states coupled

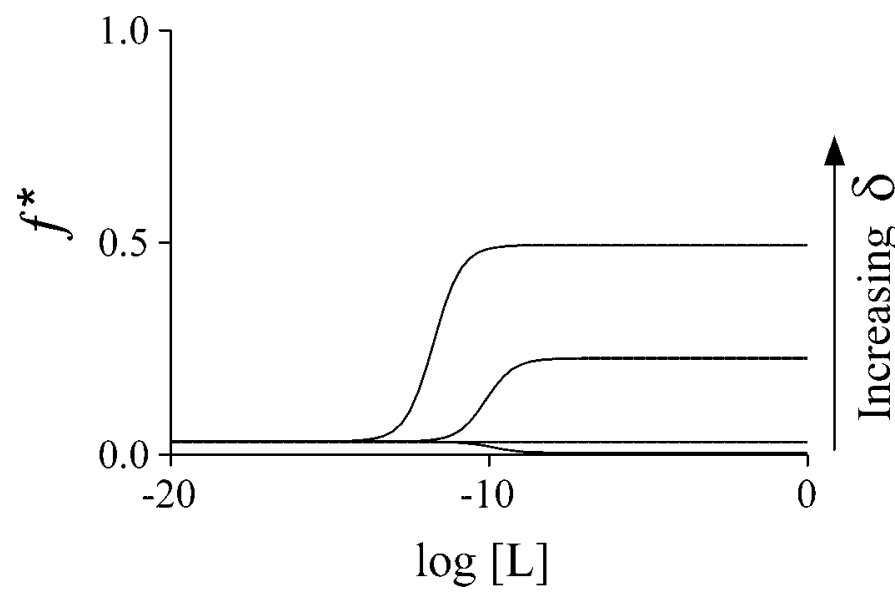

Fig. 6. Simulation of a dose-response experiment according to the CTC model. Simulation was based on Eq. 2 (see Results), using values of: $\alpha=$ $\beta=\gamma=10 ; K_{\mathrm{a}}=K_{\mathrm{g}}=10^{9} ; K_{\mathrm{act}}=10^{-2} ;[G]_{\text {total }}=0.5 ;[R]_{\text {total }}=1 ; \delta=0.01 ;$ $0.078 ; 1 ; 100$. and uncoupled to G-protein, we have to measure the ligand affinity for more than one receptor species.

If $[R]_{\mathrm{B}}$ is the receptor bound to ligand and $[R]_{\mathrm{U}}$ the free receptor concentrations, we can define an affinity constant:

$$
K_{\mathrm{a}}=[R]_{\mathrm{B}}-[A][R]_{\mathrm{U}}
$$

If we have more than one bound and free receptor species, the affinity constant corresponds to the previously mentioned apparent affinity constant, which can be expressed as:

$$
K_{\text {app }}=\frac{\sum K_{\mathrm{i}} \times\left[R_{\mathrm{i}}\right]}{\sum\left[R_{\mathrm{i}}\right]}
$$

where $K_{\mathrm{i}}$ is the ligand affinity for the $\mathrm{i}^{\text {th }}$ unbound receptor state $R_{\mathrm{i}}$. This $K_{\text {app }}$ is a weighted average of the equilibrium association constants of the ligand for the unbound receptor species.

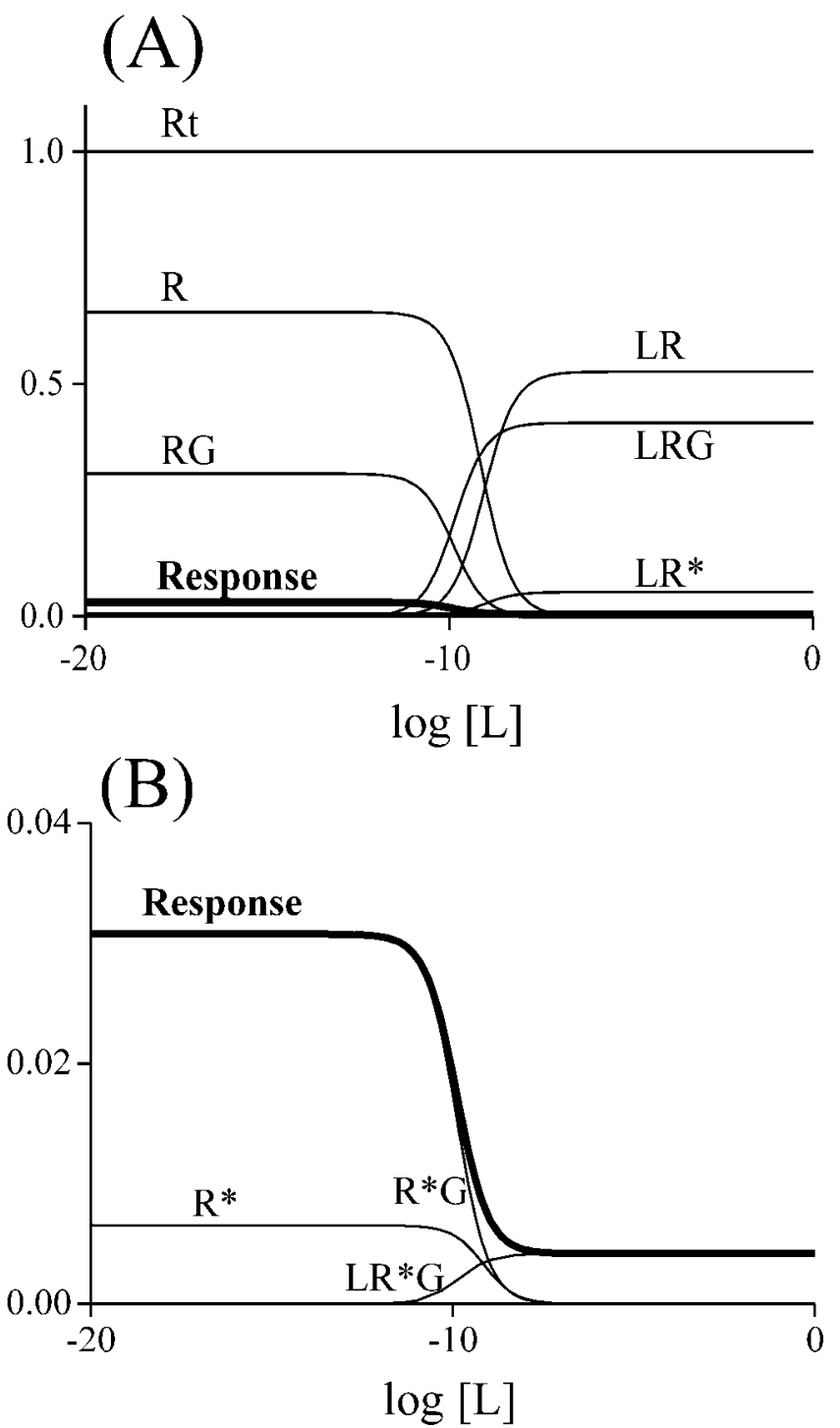

Fig. 7. A, simulation of receptor species variation depending on ligand concentration. $f^{*}$ (assumed proportional to response) is represented in bold. Simulation was based on Eqs. 3 to 10 (see Appendix 1). $\alpha=\beta=\gamma=$ $10 ; K_{\mathrm{a}}=K_{\mathrm{g}}=10^{9} ; K_{\text {act }}=10^{-2} ;[G]_{\text {total }}=0.5 ;[R]_{\text {total }}=1 ; \delta=0.01 .[R]_{\text {total }}$ was calculated as the sum of every species and the plot was added as a control of model consistency. B, axis enlargement ranging from 0 to 0.04 was added for a better observation. 
Using this equation, the apparent affinity of the ligand for the receptor species coupled $\left(K_{\operatorname{app}_{G}}\right)$ and uncoupled $\left(K_{\mathrm{app}_{N}}\right)$ to G-protein can be calculated as follows:

$$
\begin{gathered}
K_{\mathrm{appG}}=\frac{\gamma \times K_{\mathrm{a}}\left(1+\alpha \times \beta \times \delta \times K_{\mathrm{act}}\right)}{1+\beta \times K_{\mathrm{act}}} \\
K_{\mathrm{appN}}=\frac{K_{\mathrm{a}}\left(1+\alpha \times K_{\mathrm{act}}\right)}{1+K_{\mathrm{act}}}
\end{gathered}
$$

Considering this equation, and using the same values for the parameters as in Fig. 7, we can demonstrate the existence of at least one $\delta$ value for which the theoretical relation $K_{\operatorname{app}_{G}}$ ' $K_{\text {app }_{N}}(8.4)$ is quite similar to that experimentally obtained for $\left[{ }^{3} \mathrm{H}\right]$ tiotidine binding (9.1). This implies that a radiolabeled inverse agonist can label the uncoupled states with lower affinity and the coupled states with higher affinity, although it fails to signal.

\section{Discussion}

The major finding of this study is that tiotidine is an inverse agonist that binds with high affinity to a form of the receptor coupled to G-protein but inactive. Two lines of evidence strongly support our conclusion: 1) tiotidine binds with high affinity to a site that no longer exists in the presence of GTP $\gamma \mathrm{S}$ or in desensitized cells and 2) tiotidine leads to a dose-dependent decrease in cAMP basal levels in U-937 cells, an effect that is clearly evident in both homologous and heterologous overexpression systems, as well as in forskolin pretreated cells. Each of these points is discussed, and our results are then interpreted with the aid of the CTC model.

First of all, tiotidine was initially described as a potent $\mathrm{H} 2$ antagonist with reported pA2 values of 7.3 to 7.8 (guinea pig right atrium) (van der Goot et al., 1991). It was considered a selective tool to establish interactions with the H2r because of its low affinity for both the $\mathrm{H} 1$ and the $\mathrm{H} 3$ receptors (van der Goot and Timmerman, 2000). On the other hand, binding of $\left[{ }^{3} \mathrm{H}\right]$ tiotidine to gastric mucosal cells revealed the presence

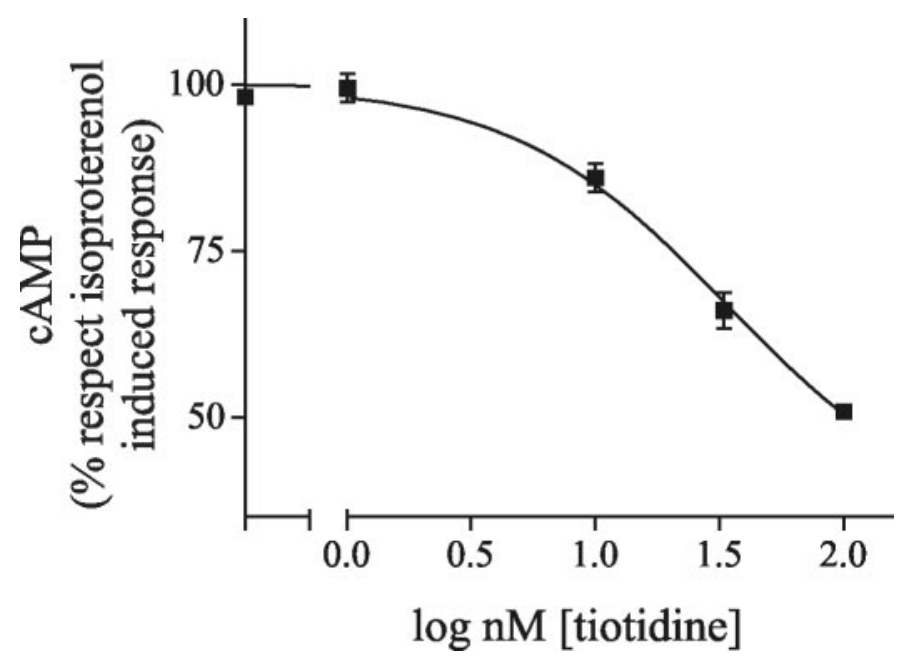

Fig. 8. Tiotidine dose-dependent reduction in isoproterenol-induced cAMP levels. U-937 cells were incubated for 3 min with increasing concentrations of tiotidine and $9 \mathrm{~min}$ with $50 \mathrm{nM}$ isoproterenol at $37^{\circ} \mathrm{C}$ in the presence of $1 \mathrm{mM}$ IBMX. Data are represented as the percentage of isoproterenol-induced cAMP levels and were calculated as the means \pm S.D. of assay triplicates. Similar results were obtained in three independent experiments. of several binding sites (Batzri and Harmon, 1986). Therefore, the use of tiotidine for selectively labeling peripheral H2rs was considered rather limited. However, these findings can be explained with our first observation that tiotidine recognizes with different affinities the G-protein-coupled and -uncoupled forms of the H2r, as can be inferred from the vanishing of the high-affinity binding site in the presence of GTP $\gamma \mathrm{S}$. This result was confirmed by studies in desensitized cells in which pretreatment with an $\mathrm{H} 2$ agonist that promotes a rapid receptor desensitization or uncoupling from heterotrimeric G-protein (Lemos et al., 2000) also leads to a single binding site for $\left[{ }^{3} \mathrm{H}\right]$ tiotidine.

GPCRs are affected by various receptor-specific ligands that modulate the GPCR activity in distinct ways. Originally, antagonists were thought to compete with the agonist for the same binding site but not to affect the GPCR activity directly. With the identification of CAM receptors, it has become clear that antagonists should be reclassified as neutral antagonists and inverse agonists.

Considering as an inverse agonist every ligand that is able to reduce the activity of receptor systems that are active in the absence of agonist, and taking into account our second observation, that tiotidine reduces cAMP basal levels in naive and surrogate systems, we believe that this ligand has to be reclassified as an $\mathrm{H} 2$ inverse agonist. Knowing that tiotidine may be regarded as an analog of cimetidine, a previously described H2 antagonist that was reclassified as an H2 inverse agonist (Smit et al., 1996), it is not surprising that this compound, which shares most of its structure with cimetidine, has a similar behavior.

It is widely assumed that inverse agonists stabilize certain states of the receptor with different functional activities. Based on the ETC model, they may act by binding to the $\mathrm{R}$ state of the receptor in preference to the $R^{*}$ state. Alternatively, they could bind to uncoupled states of the receptor ( $R$ and $\left.R^{*}\right)$ in preference to the coupled state $\left(R^{*} G\right)$. A third possibility is that inverse agonists bias the receptor to an inactive conformation that can exist in G-protein coupled and uncoupled forms. The CTC model contains an inactive receptor conformation that can nevertheless couple to G-protein and makes it a suitable model to explain our findings about both tiotidine binding and its negative efficacy. To better explain what we discussed above, it is worth considering that for the ETC model, a ligand with high affinity for receptor species coupled to G-protein necessarily elicits a response. In contrast, the CTC model implies the existence of a receptor state coupled to G-protein, which is unable to evoke a response (RG), allowing a ligand with high affinity for the receptor form coupled to G-protein to behave as an antagonist or even as an inverse agonist (Fig. 6). This point is a distinctive feature of the CTC model.

Although the development of the ETC model was made necessary by experimental observation, the CTC model was originally proposed in a attempt to explore the mathematical and pharmacological implications that can be derived from permitting G-proteins to interact with receptors in their inactive and active forms. Thus, the CTC model was the culmination of a trend in increasing model complexity and statistical and thermodynamic completeness. However, our experimental findings can be explained solely in terms of the CTC model, justifying the use of this heuristic model despite its complexity. The main implication of the present study is 
that it provides experimental support for the CTC model, showing that it has a practical use in addition to its theoretical use.

It is worth considering that another group obtained similar results for the CB1 cannabinoid receptor, which, after stimulation with a specific ligand, can couple to $\mathrm{G}_{\mathrm{i} / \mathrm{o}}$-protein without evoking a response (Bouaboula et al., 1997). Moreover, Brown and Pasternak (1998) showed that the binding of a specific $\mu$-opioid receptor ligand, functionally classified as an antagonist, labels a G-protein-coupled state of the receptor with high affinity. These observations could also be explained using the CTC model.

In terms of the CTC model, the fact that tiotidine interferes with the signal transduction pathway of the $\beta 2$-adrenoreceptor, which also involves $\mathrm{G} \alpha \mathrm{s}$-protein, implicates that tiotidine is biasing the system to a G-protein-coupled form of the H2r and making the G-protein less available to other GPCRs. This result supports the speculations based on our theoretical simulations considering a limiting G-protein concentration.

Alewijnse et al. (2000) showed that, as seen for CAM receptors, the affinity of histamine for both R116A and R116N arginine H2r mutants was significantly increased over that of the wild-type receptor. However, this increase in agonist affinity was not accompanied by an increase in constitutive receptor activity. In contrast, basal cAMP levels of both arginine mutant H2rs were significantly decreased compared with the wild-type receptors. These mutant receptors seemed to be in an active conformation, but the ability to couple to or activate G-protein was decreased. We speculate that the form of the receptor obtained in the presence of tiotidine resembles the conformation of these mutated H2rs, which has a high affinity for G-protein but fails to evoke a response.

Taking into account that the ligand-receptor interaction is very complex, a further consideration is to analyze our results in terms of the proposed existence of receptor protein as collections of microconformational states that might be pharmacologically relevant (ensemble theory; Hilser et al., 1998). In this context, it is tempting to speculate that tiotidine behaves as a ligand that preferentially binds to a microconformation coupled to G-protein but inactive, biasing the system to a non-response-evoking state. This possibility could be partly a restatement of the CTC model, because it might provide a conformational explanation for the receptor species present in it.

These results, which enlarge the knowledge about inverse agonists, not only lead to the reclassification of tiotidine as an $\mathrm{H} 2$ inverse agonist with an unusual behavior but also provide evidence to consider the CTC an experimentally supported model.

\section{Appendix 1}

An equation that describes the variation of $f^{*}$ as a function of ligand concentration can be obtained, and if we represent $f^{*}$ as a function of $\log [\mathrm{L}]$, we can simulate a theoretical dose-response assay for a given set of parameters (Fig. 6).

Taking into account Eq. 1 (see Results) and considering the model-assumed equilibrium, its related constants,

$$
K_{\mathrm{a}}=\frac{[L R]}{[L][R]} \quad K_{\text {act }}=\frac{\left[R^{*}\right]}{[R]} \quad K_{\mathrm{g}}=\frac{[R G]}{[R][G]}
$$

and the conservation equations for each component (R, G, L),

$$
\begin{gathered}
{[R]_{\text {total }}=[R]+\left[R^{*}\right]+[L R]+\left[L R^{*}\right]+[R G]+\left[R^{*} G\right]+[L R G]} \\
+\left[L R^{*} G\right] \\
{[G]_{\text {total }}=[G]+[R G]+\left[R^{*} G\right]+[L R G]+\left[L R^{*} G\right]} \\
{[L]_{\text {total }}=[L]+[L R]+\left[L R^{*}\right]+[L R G]+\left[L R^{*} G\right]}
\end{gathered}
$$

we can deduce Eq. 2 (see Results), which represents the variation in the concentration of the species capable of generating a physiological response as a function of ligand concentration [L]. In the same way, we can obtain the equations that describe the behavior of every species as a function of [L]. Let

$$
\begin{aligned}
Z= & 1+K_{\mathrm{act}}+K_{\mathrm{g}}[G]+\beta \times K_{\mathrm{g}} \times K_{\mathrm{act}}[G]+\left(K_{\mathrm{a}}+\alpha \times K_{\mathrm{a}}\right. \\
& \left.\times K_{\mathrm{act}}+\gamma \times K_{\mathrm{a}} \times K_{\mathrm{g}}[G]+\alpha \beta \gamma \delta \times K_{\mathrm{a}} \times K_{\mathrm{act}} \times K_{\mathrm{g}}[G]\right) \times[L]
\end{aligned}
$$

then

$$
\begin{gathered}
\frac{[R]}{[R]_{\text {total }}}=\frac{1}{Z} \\
\frac{[R G]}{[R]_{\text {total }}}=\frac{K_{\mathrm{g}}[G]}{Z} \\
\frac{[L R]}{[R]_{\text {total }}}=\frac{K_{\mathrm{a}}[L]}{Z} \\
\frac{[L R G]}{[R]_{\text {total }}}=\frac{\gamma \times K_{\mathrm{a}} \times K_{\mathrm{g}}[G][L]}{Z} \\
\frac{[R *]}{[R]_{\text {total }}}=\frac{K_{\mathrm{act}}}{Z} \\
\frac{[R * G]}{[R]_{\text {total }}}=\frac{\beta \times K_{\mathrm{act}} \times K_{\mathrm{g}}[G]}{Z} \\
\frac{[L R *]}{[R]_{\text {total }}}=\frac{\alpha \times K_{\mathrm{a}} \times K_{\mathrm{act}}[L]}{Z} \\
\frac{\alpha \beta \gamma \delta}{[L]_{\text {total }}}=\frac{\alpha \beta K_{\mathrm{a}} \times K_{\mathrm{act}} \times K_{\mathrm{g}}[G][L]}{Z}
\end{gathered}
$$

The model internal consistency was tested, verifying that the sum of the former quotients results in 1 for every $L$ concentration (Fig. 7).

\section{Appendix 2}

As indicated in the text, $[G]$ represents the concentration of the free G-protein and, because it is a function of the concentration of the ligand present in the system, $[G]$ must be found for each L concentration. Because $[G]$ has a quadratic dependence on $[L],[G]$ must be achieved by solving

$$
\frac{-b \pm \sqrt{b^{2}-4 \times a \times c}}{2 \times a}
$$

where

$$
\begin{aligned}
a=K_{\mathrm{g}}+\beta K_{\mathrm{g}} K_{\mathrm{act}} & +\gamma K_{\mathrm{g}} K_{\mathrm{a}}[L]+\alpha \beta \gamma \delta K_{\mathrm{g}} K_{\mathrm{act}} K_{\mathrm{a}}[L]+K_{\mathrm{g}}^{2} \\
& +\beta K_{\mathrm{g}}^{2} K_{\mathrm{act}}+\gamma K_{\mathrm{g}}^{2} K_{\mathrm{a}}[L]+\alpha \beta \gamma \delta K_{\mathrm{g}}^{2} K_{\mathrm{a}} K_{\mathrm{act}}[L]
\end{aligned}
$$




$$
\begin{gathered}
b=1+K_{\mathrm{act}}+K_{\mathrm{a}}[L]+\alpha K_{\mathrm{a}} K_{\mathrm{act}}[L]+K_{\mathrm{g}}+K_{\mathrm{g}} K_{\mathrm{act}}+K_{\mathrm{g}} K_{\mathrm{a}}[L] \\
+\alpha K_{\mathrm{g}} K_{\mathrm{act}} K_{\mathrm{a}}[L]+R t\left(\beta K_{\mathrm{g}} K_{\mathrm{act}}+\gamma K_{\mathrm{g}} K_{\mathrm{a}}[L]\right. \\
\left.+\alpha \beta \gamma \delta K_{\mathrm{g}} K_{\mathrm{act}} K_{\mathrm{a}}[L]\right)-G_{\text {total }}\left(K_{\mathrm{g}}+\beta K_{\mathrm{g}} K_{\mathrm{act}}+\gamma K_{\mathrm{g}} K_{\mathrm{a}}[L]\right. \\
\left.+\alpha \beta \gamma \delta K_{\mathrm{g}} K_{\mathrm{act}} K_{\mathrm{a}}[L]\right) \\
c=-G_{\text {total }}\left(1+K_{\mathrm{act}}+K_{\mathrm{a}}[L]+\alpha K_{\text {act }} K_{\mathrm{a}}[L]\right)
\end{gathered}
$$

\section{Acknowledgments}

We are sincerely grateful to Dr. L. Bianciotti for critical reading of the manuscript.

\section{References}

Alewijnse AE, Timmerman H, Jacobs EH, Smit MJ, Roovers E, Cotecchia S, and Leurs R (2000) The effect of mutations in the DRY motif on the constitutive activity and structural instability of the histamine $\mathrm{H} 2$ receptor. Mol Pharmacol $\mathbf{5 7 : 8 9 0 - 8 9 8}$

Batzri S and Harmon JW (1986) Is $\left[{ }^{3} \mathrm{H}\right]$-tiotidine a specific ligand for the H2receptor? Pharmacology 32:241-247.

Bouaboula M, Parrachon S, Milligan L, Canat X, Rinaldi-Carmona M, Portier M, Barth F, Calandra B, Pecceu F, Lupker J, et al. (1997) A selective inverse agonist for central cannabinoid receptor inhibits mitogen-activated protein kinase activation stimulated by insulin or insulin-like growth factor 1. J Biol Chem 272:2233022339.

Brown GP and Pasternak GW (1998) ${ }^{3} \mathrm{H}-$ Naloxone benzoylhydrazone binding in MOR-1-transfected Chinese hamster ovary cells: Evidence for G-protein- dependent antagonist binding. J Pharmacol Exp Ther 286:376-381.

Chidiac P, Hebert TE, Valiquette M, Dennis M, and Bouvier M (1994) Inverse agonist activity of $\beta$-adrenergic agonists. Mol Pharmacol 45:490-499.

Davio C, Baldi A, Shayo C, Brodsky A, Cricco G, Bergoc R and Rivera E. $\mathrm{H}_{1}$ and $\mathrm{H}_{2}$ histamine receptors in histiocytic lymphoma cell line U937. Inflamm Res 44:S72S73, 1995a.

Davio C, Cricco G, Bergoc R, and Rivera E (1995b) $\mathrm{H}_{1}$ and $\mathrm{H}_{2}$ histamine receptors in $\mathrm{N}$-nitroso-N-methylurea (NMU)-induced carcinomas with atypical coupling to signal transducers. Biochem Pharmacol 50:91-96.

De Léan A, Stadel JM, and Lefkowitz RJ (1980) A ternary complex model explains the agonist-specific binding properties of the adenylate cyclase-coupled $\beta$-adrenergic receptor. J Biol Chem 255:7108-7117.

Del Valle J and Gantz I (1997) Novel insights into histamine H2 receptor biology. Am J Physiol 273:G987-G996.

Fernández N, Monczor F, Lemos B, Notcovich C, Baldi A, Davio C, and Shayo C (2002) Reduction of G protein-coupled receptor kinase 2 expression in U-937 cells attenuates $\mathrm{H} 2$ histamine receptor desensitization and induces cell maturation. Mol Pharmacol 62:1506-1514.

Hall A and Strange PG (1997) Evidence that antipsychotic drugs are inverse agonists at D2 dopamine receptors. Br J Pharmacol 121:731-736.

Hilser VJ, Dowdy D, Oas TG, and Freire E (1998) The structural distribution of cooperative interactions in proteins: analysis of the native state ensemble. Proc Natl Acad Sci USA 18:9903-9908.

Kenakin T, Morgan P, and Lutz M (1995) On the importance of the "antagonist assumption" to how receptors express themselves. Biochem Pharmacol 50:17-26. Kjelsberg MA, Cotecchia S, Ostrowski J, Caron MG, and Lefkowitz RJ (1992) Constitutive activation of the $\alpha 1 \beta$-adrenergic receptor by all amino acid substitu- tions at a single site. Evidence for a region which constrains receptor activation. J Biol Chem 267:1430-1433.

Lemos B, Shayo C, Monczor F, Martin ME, Fernandez N, Brodsky A, Baldi A, and Davio C (2000) Rapid desensitization and slow recovery of cyclic AMP response mediated by histamine H2 receptors in U-937 cell line. Biochem Pharmacol 60: 159-166.

Leurs R, Hoffmann M, Alewijnse AE, Smit MJ, and Timmerman H (2002) Methods to determine the constitutive activity of histamine $\mathrm{H} 2$ receptors. Methods Enzymol 343:405-416.

Milligan G (1996) The stoichiometry of expression of protein components of the stimulatory adenylyl cyclase cascade and the regulation of information transfer. Cell Signal 8:87-96.

Monczor F, Legnazzi BL, Rivera E and Davio C. Tiotidine, a classical H2-antagonist, presents characteristics of an inverse agonist in U937 cell line. Inflamm Res 47:S42-43, 1998.

Munson PJ and Rodbard D (1980) Ligand: a versatile computerized approach for characterization of ligand-binding systems. Anal Biochem 107:220-239.

Parma J, Duprez L, Van Sande J, Cochaux P, Gervy C, Mockel J, Dumont J, and Vassart G (1993) Somatic mutations in the thyrotropin receptor gene cause hyperfunctioning thyroid adenomas. Nature (Lond) 365:649-651.

Rising TJ and Norris DB (1985) Histamine H2 receptor radioligand studies, in Frontiers in Histamine Research (Ganellin CR and Schwartz JC eds) pp 61-67, Pergamon, Oxford.

Rossier O, Abuin L, Fanelli F, Leonardi A, and Cotecchia S (1999) Inverse agonism and neutral antagonism at $\alpha_{1 \mathrm{a}}$ and $\alpha_{1 \mathrm{~b}}$ adrenergic receptor subtypes. Mol Phar macol 56:858-866.

Samama P, Cotecchia S, Costa T, and Lefkowitz RJ (1993) A mutation-induced activated state of the $\beta 2$-adrenergic receptor. Extending the ternary complex model. J Biol Chem 268:4625-4636.

Shayo C, Fernandez N, Lemos Legnazzi B, Monczor F, Mladovan A, Baldi A, and Davio C (2001) Histamine $\mathrm{H}_{2}$ receptor desensitization. Involvement of a select array of G protein-coupled receptor kinases. Mol Pharmacol 60:1049-1056.

Shenker A, Laue L, Kosugi S, Merendino JJ Jr, Minegishi T, and Cutler GB Jr (1993) A constitutively activating mutation of the luteinizing hormone receptor in familial male precocious puberty. Nature (Lond) 365:652-654.

Smit MJ, Leurs R, Alewijnse AE, Blauw J, Van Nieuw Amerongen GP, Van De Vrede $\mathrm{Y}$, Roovers E, and Timmerman H (1996) Inverse agonism of histamine H2 antagonists accounts for up-regulation of spontaneously active histamine $\mathrm{H} 2$ receptors. Proc Natl Acad Sci USA 93:6802-6807.

van der Goot H, Bast A, and Timmerman H (1991) Structural requirements for histamine $\mathrm{H} 2$ agonists and $\mathrm{H} 2$ antagonists, in Handbook of Experimental Phar macology, Vol 97 (Arrang J-M, Uvnäs Bed) pp 573-748, Springer-Verlag, Berlin. van der Goot $\mathrm{H}$ and Timmerman $\mathrm{H}$ (2000) Selective ligands as tools to study histamine receptors. Eur J Med Chem 35:5-20.

Weiss JM, Morgan PH, Lutz MW, and Kenakin TP (1996a) The cubic ternary complex receptor-occupancy model. I. Model description. J Theor Biol 178:151167.

Weiss JM, Morgan PH, Lutz MW, and Kenakin TP (1996b) The cubic ternary complex receptor-occupancy model. II. Understanding apparent affinity. J Theor Biol 178:169-182.

Weiss JM, Morgan PH, Lutz MW, and Kenakin TP (1996c) The cubic ternary complex receptor hyphen occupancy model. III. Resurrecting efficacy. J Theor Biol 181:381-397.

Westphal RS and Sanders-Bush E (1994) Reciprocal binding properties of 5HT2c receptor agonists and antagonists. Mol Pharmacol 46:937-942.

Address correspondence to: Dr. Davio Carlos, Laboratorio de Radioisótopos, Facultad de Farmacia y Bioquímica, Universidad de Buenos Aires. Junin 956 PB, 1113, Capital Federal, Argentina. E-mail: cardavio@ffyb.uba.ar 